\title{
段波モデルを用いた孤立波の崩れ波型砕波の一解析

\author{
MACROSCOPIC ANALYSIS ON A SPILLING BREAKER OF \\ SOLITARY WAVE BY USING A BORE MODEL
}

\author{
松富英夫* \\ By Hideo MATSUTOMI
}

\begin{abstract}
This paper presents a simple analytical model for predicting the transformation of a bore caused by the spilling breaker of a solitary wave over a horizontal bed. The basic equations used are the laws of mass and momentum conservation, in which the pressure terms are corrected to include the effects of a deviation from the hydrostatic pressure and a non-uniformity of the velocity distribution. The surface profile is evaluated on the assumption that the flow field of the bore is similar to that of a dam-break flow. The validity of the solutions is examined through comparison with the results of laboratory experiments. It is found that the present model is applicable to the bore transformation over a horizontal bed except for a short period after the formation of the bore.
\end{abstract}

Keywords : spilling breaker, bore, tsunami, dam-break flow, wave transformation

\section{1. まえがき}

段波そのものの斜面上での変形特性や砕波津波の陸上 遡上高の推定を目的としたものを除けば，砕波後の波の 変形に関する研究は, 崩れ波型と巻き波型砕波を種々モ デル化することにより，主に波高減衰を中心に海浜流や 海浜変形に関連して行われてきた（従来の砕波後の波の 変形に関する研究の総括は文献 1 ）と 2 ）に詳しい). 波高減衰に関しては代表的海底地形に対してかなりの知 見が得られてきており，海浜流の数值計算などという実 用にも供されつつあるが3), 海岸構造物などへの波力は もとより，波力の算定 ${ }^{4}$ などにおいて必要とされる硒波 面の伝播速度，砕波部そのものの高さやその水面形につ いては実験的にも理論的にもほとんど検討されておらず 未解明の状態にある。

ところで, 1983 年日本海中部地震津波は秋田県北部 海岸でソリトン波列や分裂には至らなかった孤立的な波 を形成し，砕波しながら陸上へ遡上した。そのためか， 海岸構造物として設置されていた異型ブロックが通常の 短周期波では考えられないような被害の受け方をし，津 波によるソリトン波列や孤立的な波の砕波時の水面形,

* 正会員 工修 秋田大学助手 鉱山学部土木工学科 （干010 秋田市手形学園町 1-1）
波力やエネルギー消費機構などが津波問題において取り 上げられようとしている5゙.

以上の波の砕波変形問題の研究の状況と必要性に基つ き，本研究は津波によって形成され得るソリトン波列や 孤立的な波を対象として，その個々の波は巨視的には孤 立波理論の適用できる波であるという考えに立ち，最も 基本的な水平床上での孤立波の崩れ波型砕波による波高 減衰および砕波面の伝播速度，砕波部の高さとその水面 形を簡単なモデルで理論的に推定することを試みようと したものである.

解析手法は質量と抵抗力を考慮した(抵抗力を考慮し, その効果を論じた研究として文献 6$) ， 7$ )，8）などが ある）運動量の保存則に基づく段波モデル法である．段 波モデル法では砕波面の伝播を精度よく表現できないと 実験的に指摘されてきたが(1),6)，流速分布や圧力の非静 水圧性を考虑して運動量フラックスと圧力の補正を行う ことでその適用性を高めることにする．巨視的な砕波後 の波の諸変形特性を解析的に推定することを目的として いるのである.

\section{2. 基 本 式}

孤立波の伝播速度で動く移動座標系で議論することに する．また，孤立波理論としては次の Boussinesq の第 
1 近似解を用いることにする ${ }^{9)}$.

$$
\begin{aligned}
& \eta=H_{b} \operatorname{sech}^{2}\left[\sqrt{\frac{3 H_{b}}{4 h^{3}}}\left(x-c_{s} t\right)\right] . \\
& c_{s}=\sqrt{g\left(h+H_{b}\right)}=\sqrt{g D} \\
& u=\frac{c_{s} \eta}{h+\eta}=\frac{c_{s} \eta}{H}
\end{aligned}
$$

ここで, $\eta$ : 静水面からの水位, $H_{b}$ : 孤立波の砕波波高, $h$ : 静水深, $c_{s}$ : 孤立波の伝播速度, $u$ : 断面平均水粒 子速度, $D$ : 砕波開始時の波頂での全水深, $H$ : 任意点 での全水深, $g$ : 重力加速度, $x$ : 岸向きの水平距離座 標で砕波点を原点とする, $t:$ 時間で砕波時を原点とす る. よって, 式 (2) の伝播速度で動く移動座標系での 孤立波の諸量は

$$
\begin{aligned}
& \eta=H_{b} \operatorname{sech}^{2}\left(\sqrt{\frac{3 H_{b}}{4 h^{3}}} X\right) . \\
& c=c_{s}-c_{s}=0 \cdots \ldots \ldots \ldots \ldots \\
& U=u-c_{s}=-\frac{c_{s} h}{H} \cdots \cdots \ldots
\end{aligned}
$$

ここで, $X, c$ とUはおのおの移動座標系での水平距 離座標, 伝播速度と断面平均水粒子速度である. 式 (6) より，移動座標系での孤立波における流量はあらゆる点 で

$$
H U=-c_{s} h=\text { const. }
$$

であると判断される.

ところで，図一1に示すように，本研究では孤立波は 崩れ波型砕波により伝播方向に断面平均水粒子速度の一 様な領域と坬立波の諸性質をそのまま保持し続ける領域 の 2 つに分けられると仮定して議論する.この断面平均 水粒子速度の伝播方向への一梯性の仮定は同じ砕波段波 を形成するダム破壊流れ問題で用いられているものであ $3^{10)}$. よって, 伝播方向への断面平均水粒子速度一様域 の諸水理量を求めることが本研究の目的となる.そして, 本研究ではそれらをその領域全体の連続式と運動量式を 誘導して解くことにより求めることにする.

いま本領域後端位置を $\xi$, そこでの全水深と断面平均 水粒子速度をそれぞれ $H_{\mathrm{g}}$ と $U_{\mathrm{g}}$, 領域先端位置を $a$, そ こでの全水深と孤立波の性質を有する側の断面平均水粒 子速度をそれぞれ $H_{a}$ と $U_{a}$, 水の密度を $\rho$ とすると, $X$ $=\xi$ から単位時間に本領域に流入する質量 $M_{i n}$ は $\xi$ が時 間的に移動し得るものなので

$$
M_{i n}=\rho H_{s}\left(U_{s}-\frac{d \xi}{d t}\right)
$$

一方, $X=a$ から単位時間に流出する質量 $M_{o u t}$ は

$$
M_{\text {out }}=\rho H_{a}\left(U_{a}-\frac{d a}{d t}\right)
$$

よって, 本領域の連続式は

$$
\frac{d M}{d t}=M_{i n}-M_{o u t}
$$

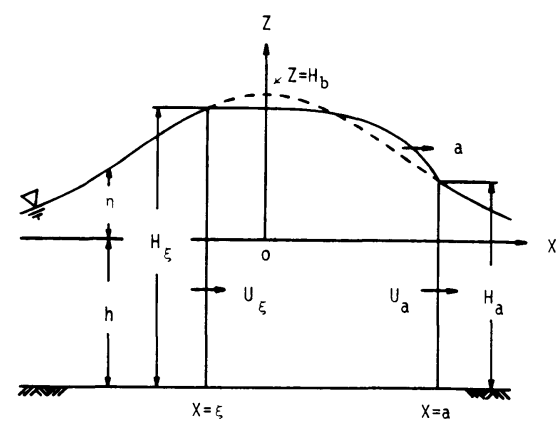

図一1本研究モデルと記号

$$
\begin{aligned}
& =\rho H_{\xi}\left(U_{\xi}-\frac{d \xi}{d t}\right)+\rho H_{a}\left(\frac{d a}{d t}-U_{a}\right) \\
& =\rho H_{a} \frac{d a}{d t}-\rho H_{\xi} \frac{d \xi}{d t}
\end{aligned}
$$

ここで, $M$ は本領域の全質量で, 式 $(7)$ の関係が使 用されている.

次に, $X=\xi$ から単位時間に本領域に流入する運動量 $P_{\text {in }}$ は

$$
P_{i n}=\rho H_{\xi} U_{\xi}\left(\beta^{\prime} U_{\xi}-\frac{d \xi}{d t}\right) .
$$

また, $X=a$ より単位時間に流出する運動量 $P_{\text {out }}$ は

$$
P_{\text {out }}=\rho H_{a} U_{a}\left(\beta^{\prime} U_{a}-\frac{d a}{d t}\right) \text {. }
$$

ここで， $\beta^{\prime}$ は運動量補正係数である. そして, 本領域 の境界に働く外力 $F$ は本領域後端と先端での圧力およ び底面抵抗の 3 つである. 以上より本領域の運動量式は

$$
\begin{aligned}
\frac{d P}{d t}= & P_{\text {tn }}-P_{o u t}+F \\
= & \rho H_{\xi} U_{\xi}\left(U_{\xi}-\frac{d \xi}{d t}\right)+\rho H_{a} U_{a}\left(\frac{d a}{d t}-U_{a}\right) \\
& +\frac{r^{2}}{2} \rho g H_{\xi}^{2}-\frac{r^{2}}{2} \rho g H_{a}^{2}-\rho K\left(U_{\xi}+c_{s}\right)^{2}(a-\xi)
\end{aligned}
$$

ここで, $P$ : 本領域の全運動量, $r^{2}$ : 圧力と運動量フラッ クス（圧力に換算）の合成補正係数， $K$ : 抵抗係数であ り, 運動量補正係数 $\beta^{\prime}$ は $r^{2}$ の導入により 1 とされてい る.ただし, $r^{2}$ は本研究対象区間での平均的な值の定 数と仮定し, 底面せん断応力は $\tau_{0}=\rho K\left(U_{s}+c_{s}\right)^{2}$ と定 義している. $r^{2}$ のだいたいの值は理論的に評価し得る ものである (4. (2) と補遺参照).

さて, 仮定から得られる $P=M U_{\xi}$ の関係を用いると, 式（10）および式（13）から

$$
\begin{aligned}
M \frac{d U_{\xi}}{d t}= & \frac{r^{2}}{2} \rho g H_{\xi}^{2}-\frac{r^{2}}{2} \rho g H_{a}^{2}-\rho H_{a}\left(U_{s}-U_{a}\right) \\
& \cdot\left(\frac{d a}{d t}-U_{a}\right)-\rho K\left(U_{\xi}+c_{s}\right)^{2}(a-\xi) \cdots
\end{aligned}
$$

また, $M$ は本領域外での水面形を不変としているので 


$$
\begin{aligned}
M= & \rho \int_{\xi}^{a} H d X=\rho \int_{\xi}^{a}\left[h+H_{b} \operatorname{sech}^{2}\left(\sqrt{\frac{3 H_{b}}{4 h^{3}}} X\right)\right] d X \\
= & \rho h(a-\xi)+\rho \sqrt{\frac{4}{3} h^{3} H_{b}}\left[\tanh \left(\sqrt{\frac{3 H_{b}}{4 h^{3}}} a\right)\right. \\
& \left.-\tanh \left(\sqrt{\frac{3 H_{b}}{4 h^{3}}} \xi\right)\right] \cdots \cdots \cdots \cdots \cdots \cdots \cdots \cdots \cdots \cdots(15)
\end{aligned}
$$

よって, 式 (14) は

$$
\begin{aligned}
& {\left[h(a-\xi)+\sqrt{\frac{4}{3} h^{3} H_{b}}\left\{\tanh \left(\sqrt{\frac{3 H_{b}}{4 h^{3}}} a\right)\right.\right.} \\
& \left.\left.-\tanh \left(\sqrt{\frac{3 H_{b}}{4 h^{3}}} \xi\right)\right\}\right] \frac{d U_{\xi}}{d t} \\
& =\frac{g}{2} r^{2} H_{\xi}^{2}-\frac{g}{2} r^{2} H_{a}^{2}-H_{a}\left(U_{\xi}-U_{a}\right)\left(\frac{d a}{d t}-U_{a}\right) \\
& -K\left(U_{s}+c_{s}\right)^{2}(a-\xi)
\end{aligned}
$$

さらに, 式 (4) および（7）から次式が得られる.

$$
\begin{aligned}
& \xi=-\sqrt{\frac{4 h^{3}}{3 H_{b}}} \cosh ^{-1}\left[\sqrt{-\frac{H_{b} U_{\xi}}{h\left(U_{s}+c_{s}\right)}}\right] \\
& H_{\mathrm{e}}=-\frac{c_{s} h}{U_{\xi}} \text {. } \\
& H_{a}=h+H_{b} \operatorname{sech}^{2}\left(\sqrt{\frac{3 H_{b}}{4 h^{3}}} a\right) \\
& U_{a}=-\frac{c_{s} h}{h+H_{b} \operatorname{sech}^{2}\left(\sqrt{\frac{3 H_{b}}{4 h^{3}}} a\right)} .
\end{aligned}
$$

結局, 式（17）から（20）を式（16）に代入すれば,

$$
\begin{aligned}
& {\left[h\left\{a+\sqrt{\frac{4 h^{3}}{3 H_{b}}} \cosh ^{-1}\left(\sqrt{-\frac{H_{b} U_{\xi}}{h\left(U_{\xi}+c_{s}\right)}}\right)\right\}\right.} \\
& \left.+\sqrt{\frac{4}{3} h^{3} H_{b}}\left\{\tanh \left(\sqrt{\frac{3 H_{b}}{4 h^{3}}} a\right)+\sqrt{\frac{D U_{\xi}+h c_{s}}{H_{b} U_{\xi}}}\right\}\right] \frac{d U_{\xi}}{d t} \\
& =\frac{g}{2} r^{2} h^{2}\left(\frac{c_{s}}{U_{\xi}}\right)^{2}-\frac{g}{2} r^{2}\left\{h+H_{b} \operatorname{sech}^{2}\left(\sqrt{\frac{3 H_{b}}{4 h^{3}}} a\right)\right\}^{2} \\
& -\left[\left\{h+H_{b} \operatorname{sech}^{2}\left(\sqrt{\frac{3 H_{b}}{4 h^{3}}} a\right)\right\} U_{\xi} \dot{a}+h c_{s}\left(U_{\xi}+\dot{a}\right)\right. \\
& \left.-\frac{h^{2} c_{s}^{2}}{h+H_{b} \operatorname{sech}^{2}\left(\sqrt{\frac{3 H_{b}}{4 h^{3}}} a\right)}\right] \\
& -K\left(U_{\xi}+c_{s}\right)^{2}\left[a+\sqrt{\frac{4 h^{3}}{3 H_{b}}} \cosh ^{-1}\left\{\sqrt{-\frac{H_{b} U_{\xi}}{h\left(U_{s}+c_{s}\right)}}\right\}\right]
\end{aligned}
$$

ここで, $\dot{a}=d a / d t$.

式 (21) には水粒子速度 $U_{\xi}$ と先端位置 $a$ の 2 つの未 知数が含まれており, 方程式は閉じていない。 $U_{\varepsilon}$ と $a$ の間に何らかの新たな関係式が必要である. そこで, 本 研究では $U$, と先端移動速度 $\dot{a}$ との間に次の関係を導入 して解くことにする.

$$
\dot{a} \fallingdotseq U_{a}+r \sqrt{g H_{a}} \sqrt{\frac{1}{2} \frac{H_{\xi}}{H_{a}}\left(\frac{H_{s}}{H_{a}}+1\right)}
$$

$$
\doteqdot U_{a}+r \sqrt{g H_{s}}=U_{a}+r \sqrt{-\frac{g h c_{s}}{U_{s}}}
$$

式（22）は式（10），(13）で非定常項と抵抗項を無視し たのち, $\dot{a}=\dot{\xi}$ として得られる理想段波モデル式の一部 分に $H_{\varepsilon} \doteqdot H_{a}$ の関係を用いて誘導した近似式である. し かし, 式 (22) を式 (21) に代入して得られるものはそ のままでは簡単に解けそうにない。本研究では砕波後の あまり長くない間を対象とすることでその解決が図られ る. よって, 水平床上での特徴である波の再生までは対 象としていない.このとき, $a$ と $\xi$ は小さく, それら による Taylor 展開式の第 2 項までを考慮する近似化を 行えば,

$$
\begin{aligned}
& H_{a}=h+H_{b}\left(1-\frac{3 H_{b}}{4 h^{3}} a^{2}\right) \cdots \cdots \\
& U_{a}=-\frac{h c_{s}}{h+H_{b}\left(1-\frac{3 H_{b}}{4 h^{3}} a^{2}\right)} . \\
& \frac{M}{\rho}=D(a-\xi)-\frac{H_{b}^{2}}{4 h^{3}}\left(a^{3}-\xi^{3}\right)
\end{aligned}
$$

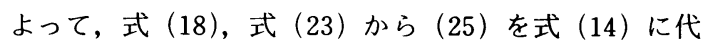
入し, $0\left(a^{2}, \xi^{2}\right)$ までを考慮すると

$$
\begin{aligned}
& D^{2}(a-\xi) U_{\xi}^{2} \frac{d U_{\xi}}{d t} \\
& =\frac{g}{2} r^{2} h^{2}\left(D-\frac{3 H_{b}^{2}}{4 h^{3}} a^{2}\right) c_{s}^{2}-\frac{r^{2}}{2} D\left(D-\frac{9 H_{b}^{2}}{4 h^{3}} a^{2}\right) c_{s}^{2} U_{\xi}^{2} \\
& \quad-\left[D\left(D-\frac{3 H_{b}^{2}}{2 h^{3}} a^{2}\right) U_{s} \dot{a}+h c_{s}\left(D-\frac{3 H_{b}^{2}}{4 h^{3}} a^{2}\right)\left(U_{s}+\dot{a}\right)\right. \\
& \left.\quad+h^{2} c_{s}^{2}\right] U_{s}^{2}-K D(a-\xi)\left(U_{s}+c_{s}\right)^{2} U_{\xi}^{2} \cdots \cdots \cdots \cdots(26)
\end{aligned}
$$

また, $\dot{a}$ と $\xi$ の関係は式 (22) から近似的に次式のよ うに置けよう.

$$
\begin{aligned}
& \dot{a} \fallingdotseq U_{a}+r \sqrt{g H_{s}} \fallingdotseq U_{a}+r c_{s} \sqrt{1-\frac{3 H_{b}^{2}}{4 h^{3} D} \xi^{2}} \\
& \doteqdot U_{a}+r c_{s}\left(1+\mu \sqrt{\frac{3 H_{b}^{2}}{4 h^{3} D}} \xi\right)
\end{aligned}
$$

ここで, $\mu(>0)$ は $\dot{a}$ と $\xi$ 間に線形的関係を得たいが

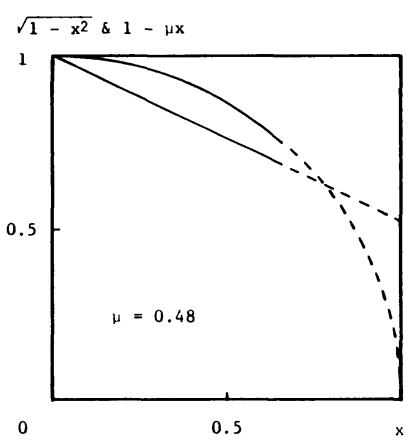

図一2 式 (27) での近似方法 
ゆえに導入された係数で，不変定数として扱われる. 本 来は， $r^{2}$ と同じく, $K$ と $t$ (換言すれば， $a$ または $\xi$ ) に関係するものである. 式 (27) の近似は，図一2に示 すように，円弧を直線で近似したことに相当している. よって, 式 (22) および（27）を式（26）に代入すれば,

$$
\begin{aligned}
& \frac{2 g r^{2} D^{2} h c_{s}}{\left(\dot{a}-U_{a}\right)^{3}}\left[a+\frac{1}{\mu} \sqrt{\frac{4 h^{3} D}{3 H_{b}^{2}}}\left\{1-\frac{1}{r c_{s}}\left(\dot{a}-U_{a}\right)\right\}\right] \\
& \cdot\left\{\ddot{a}+\frac{3 H_{b}^{2} c_{s} a \dot{a}}{2 h^{2}\left(D-\frac{3 H_{b}^{2}}{4 h^{3}} a^{2}\right)^{2}}\right\} \\
& =\frac{D}{2 g r^{2}}\left(\dot{a}-U_{a}\right)^{4}\left(1-\frac{3 H_{b}^{2}}{4 h^{3} D} a^{2}\right) \\
& -\frac{r^{2}}{2} c_{s}^{2} D^{2}\left(1-\frac{9 H_{b}^{2}}{4 h^{3} D} a^{2}\right) \\
& -\left[-g r^{2} D^{2} h\left(1-\frac{3 H_{b}^{2}}{2 h^{3} D} a^{2}\right) \frac{c_{s} \dot{a}}{\left(\dot{a}-U_{a}\right)^{2}}\right. \\
& \left.+c_{s} h D\left(1-\frac{3 H_{b}^{2}}{4 h^{3} D} a^{2}\right)\left\{\dot{a}-\frac{g r^{2} h c_{s}}{\left(\dot{a}-U_{a}\right)^{2}}\right\}+c_{s}^{2} h^{2}\right] \\
& -K D\left[a+\frac{1}{\mu} \sqrt{\frac{4 h^{3} D}{3 H_{b}^{2}}}\left\{1-\frac{1}{r c_{s}}\left(\dot{a}-U_{a}\right)\right\}\right] \\
& \cdot\left\{c_{s}-\frac{g r^{2} h c_{s}}{\left(\dot{a}-U_{a}\right)^{2}}\right\}^{2}
\end{aligned}
$$

式 (28) が本研究の基本式である.

\section{3. 基本式の解}

砕波段波先端の初期移動速度 $\dot{a}_{0}$ は式 $(7) ，(22)$ よ り

$$
\dot{a}_{0}=\left(r-\frac{h}{D}\right) c_{s}
$$

そこで, 式 (28) を解くにあたって次の無次元変数を新 たに導入することにする.

$$
\begin{gathered}
\alpha=\left(\dot{a}_{0} t-a\right) \frac{K}{D} . \\
\tau=\sqrt{\frac{g}{D}} K t \cdots .
\end{gathered}
$$

ここで， $\alpha$ は初期先端移動速度のままで砝波始点から継 続的に移動する点に対する実際の砕波段波先端の無次元 遅れ距離を示し, $\tau$ はその遅れが生じ始めてからの無次 元経過時間を示す. 式 (30) および (31) を用いて式 (28) を書き直すと,

$$
\begin{aligned}
- & 2 r^{2} h\left[\left(\dot{a}_{0} \tau-c_{s} \alpha\right)+\frac{K c_{s}}{r \mu} \sqrt{\frac{4 h^{3}}{3 H_{b}^{2} D}} \dot{\alpha}-\frac{c_{s}}{K g \mu} \sqrt{\frac{4 h^{3}}{3 H_{b}^{2} D}}\right. \\
& \left.\cdot\left(3 \frac{H_{b}^{2}}{r h^{3}} \dot{\alpha}+\frac{3 H_{b}^{2}}{4 r h^{2} D}\right)\left(\dot{a}_{0} \tau-c_{s} \alpha\right)^{2}\right][D(r-\dot{\alpha}) \ddot{\alpha} \\
& \left.-\frac{3 H_{b}^{2}}{2 g h^{2} K^{2}}(r-\dot{\alpha})\left(\dot{a}_{0} \tau-c_{s} \alpha\right)\left(\dot{a}_{0}-c_{s} \dot{\alpha}\right)\right] \\
= & \frac{1}{2 r^{2}}\left[D^{2} c_{s}(r-\dot{\alpha})^{8}-\frac{6 H_{b}^{2}}{g h^{3} K^{2}} D^{2}(r-\dot{\alpha})^{7}\right.
\end{aligned}
$$

$$
\begin{aligned}
& \left.-\left(\dot{a}_{0} \tau-c_{s} \alpha\right)^{2}\left(\dot{a}_{0}-c_{s} \dot{\alpha}\right)\right] \\
& -\frac{r^{2}}{2}\left[D^{2} c_{s}(r-\dot{\alpha})^{4}\right. \\
& -\frac{9 H_{b}^{2}}{2 g h^{3} K^{2}} D^{2} c_{s}(r-\dot{\alpha})^{4}\left(\dot{a}_{0} \tau-c_{s} \alpha\right)^{2} \\
& \left.-\frac{3 H_{b}^{2}}{g h^{3} K^{2}} D^{2}(r-\dot{\alpha})^{3}\left(\dot{a}_{0} \tau-c_{s} \alpha\right)^{2}\left(\dot{a}_{0}-c_{s} \dot{\alpha}\right)\right] \\
& -\left[( r - \dot { \alpha } ) ^ { 3 } \left\{h D(r-\dot{\alpha})\left(\dot{a}_{0}-c_{s} \dot{\alpha}\right)+h^{2} c_{s}(r-\dot{\alpha})\right.\right. \\
& \left.-r^{2} h D c_{s}\right\}+\frac{3 H_{b}^{2}}{4 g h^{3} K^{2}}(r-\dot{\alpha})^{2}\left(6 r^{2} h D\left(\dot{a}_{0}-c_{s} \dot{\alpha}\right)\right. \\
& -4 \frac{h D}{c_{s}}(r-\dot{\alpha})\left(\dot{a}_{0}-c_{s} \dot{\alpha}\right)^{2}+3 r^{2} h^{2} c_{s} \\
& -4 h D(r-\dot{\alpha})^{2}\left(\dot{a}_{0}-c_{s} \dot{\alpha}\right)-4 h^{2}(r-\dot{\alpha})\left(\dot{a}_{0}-c_{s} \dot{\alpha}\right) \\
& \left.-3 h^{2} c_{s}(r-\dot{\alpha})^{2}+3 r^{2} h D c_{s}(r-\dot{\alpha})\left(\dot{a}_{0} \tau-c_{s} \alpha\right)^{2}\right] \\
& -r^{2}\left[\left(\dot{a}_{0} \tau-c_{s} \alpha\right)+\frac{K c_{s}}{r \mu} \sqrt{\frac{4 h^{3}}{3 H_{b}^{2} D}} \dot{\alpha}-\frac{c_{s}}{K g \mu} \sqrt{\frac{4 h^{3}}{3 H_{b}^{2} D}}\right. \\
& \left.\cdot\left(3 \frac{H_{b}^{2}}{r h^{3}} \dot{\alpha}+\frac{3 H_{b}^{2}}{4 r h^{2} D}\right)\left(\dot{a}_{0} \tau-c_{s} \alpha\right)^{2}\right]\left(r H_{b}-2 D \dot{\alpha}\right)^{2}
\end{aligned}
$$

ここで, $\dot{\alpha}=d \alpha / d \tau, \ddot{\alpha}=d^{2} \alpha / d \tau^{2}$. さらに, 次の変数 を新たに導入する.

$$
\begin{aligned}
& p=\dot{\alpha} \text {. } \\
& \tau=\frac{d f}{d p}=f^{\prime}(p)
\end{aligned}
$$

これにより,独立変数の変域は半無限領域から有限領域, $0 \leqq p \leqq r-h / D$ となり， $\alpha=p f^{\prime}-f, \ddot{\alpha}=1 / f^{\prime \prime}$ となる. よって, 式 (32) は

$$
\begin{aligned}
& -2 r^{2} h\left[\left(\dot{a}_{0} f^{\prime}-c_{s} p f^{\prime}+c_{s} f\right)\right. \\
& +\frac{K c_{s}}{r \mu} \sqrt{\frac{4 h^{3}}{3 H_{b}^{2} D}} p-\frac{c_{s}}{K g \mu} \sqrt{\frac{4 h^{3}}{3 H_{b}^{2} D}} \\
& \left.+\left(3 \frac{H_{b}^{2}}{r h^{3}} p+\frac{3 H_{b}^{2}}{4 r h^{2} D}\right)\left(\dot{a}_{0} f^{\prime}-c_{s} p f^{\prime}+c_{s} f\right)^{2}\right][D(r-p) \\
& \left.-\frac{3 H_{b}^{2}}{2 g h^{2} K^{2}}(r-p)\left(\dot{a}_{0} f^{\prime}-c_{s} p f^{\prime}+c_{s} f\right)\left(\dot{a}_{0}-c_{s} p\right) f^{\prime \prime}\right] \\
& =\frac{1}{2 r^{2}}\left[D^{2} c_{s}(r-p)^{8}-\frac{6 H_{b}^{2}}{g h^{3} K^{2}} D^{2}(r-p)^{7}\right. \\
& \left.+\left(\dot{a}_{0} f^{\prime}-c_{s} p f^{\prime}+c_{s} f\right)^{2}\left(\dot{a}_{0}-c_{s} p\right)\right] f^{\prime \prime} \\
& -\frac{r^{2}}{2}\left[D^{2} c_{s}(r-p)^{4}\right. \\
& -\frac{9 H_{b}^{2}}{2 g h^{3} K^{2}} D^{2} c_{s}(r-p)^{4}\left(\dot{a}_{0} f^{\prime}-c_{s} p f^{\prime}\right. \\
& \left.+c_{s} f\right)^{2}-\frac{3 H_{b}^{2}}{g h^{3} K^{2}} D^{2}(r-p)^{3}\left(\dot{a}_{0} f^{\prime}-c_{s} p f^{\prime}\right. \\
& \left.\left.+c_{s} f\right)^{2}\left(\dot{a}_{0}-c_{s} p\right)\right] f^{\prime \prime} \\
& \quad-\left[( r - p ) ^ { 3 } \left(h D(r-p)\left(\dot{a}_{0}-c_{s} p\right)\right.\right. \\
& \left.+h^{2} c_{s}(r-p)-r^{2} h D c_{s}\right\} \\
& +\frac{3 H_{b}^{2}}{4 g h^{3} K^{2}}(r-p)^{2}\left\{6 r^{2} h D\left(\dot{a}_{0}-c_{s} p\right)-4 \frac{h D}{c_{s}}(r-p)\right.
\end{aligned}
$$




$$
\begin{aligned}
& \cdot\left(\dot{a}_{0}-c_{s} p\right)^{2}+3 r^{2} h^{2} c_{s}-4 h D(r-p)^{2}\left(\dot{a}_{0}-c_{s} p\right) \\
& -4 h^{2}(r-p)\left(\dot{a}_{0}-c_{s} p\right)-3 h^{2} c_{s}(r-p)^{2} \\
& \left.\left.+3 r^{2} h D c_{s}(r-p)\right\}\left(\dot{a}_{0} f^{\prime}-c_{s} p f^{\prime}+c_{s} f\right)^{2}\right] f^{\prime \prime} \\
& -r^{2}\left[\left(\dot{a}_{0} f^{\prime}-c_{s} p f^{\prime}+c_{s} f\right)+\frac{K c_{s}}{r \mu} \sqrt{\frac{4 h^{3}}{3 H_{b}^{2} D}} p\right. \\
& -\frac{c_{s}}{K g \mu} \sqrt{\frac{4 h^{3}}{3 H_{b}^{2} D}}\left(\frac{3 H_{b}^{2}}{r h^{3}} p+\frac{3 H_{b}^{2}}{4 r h^{2} D}\right)\left(\dot{a}_{0} f^{\prime}-c_{s} p f^{\prime}\right. \\
& \left.\left.+c_{s} f\right)^{2}\right]\left(r H_{b}-2 D p\right)^{2} \ldots \ldots \ldots \ldots \ldots \ldots \ldots \ldots \ldots \ldots(35)
\end{aligned}
$$

式 (35) は $f(p)$ に関する二階の常微分方程式である. その解として $p$ の級数解

$$
f(p)=b_{0}+b_{1} p+b_{2} p^{2}+b_{3} p^{3}+\cdots
$$

を仮定し, 初期条件（ $\tau=0$ のとき, $\alpha=\dot{\alpha}=0)$ のもと で解くことにする. 式 (36) を式 (35) に代入し，pに 関して恒等的に成立するように各係数を決めると，たと えば級数解の第一近似として次式が得られる.

$$
\begin{aligned}
b_{2}= & {\left[-\left\{\frac{D}{r}(r D-h)^{2}+\frac{K}{2 r \mu} H_{b}^{2} D \sqrt{\frac{4 h^{3}}{3 H_{b}^{2} D}}\right\}\right.} \\
& +\sqrt{\frac{D^{2}}{r^{2}}(r D-h)^{4}+\frac{K^{2}}{3 r^{2} \mu^{2}} H_{b}^{2} h^{3} D+\frac{K}{r^{2} \mu} H_{b}^{2} D^{2}} \\
& \left.\frac{\cdot\left(r^{2} D^{2}-h^{2}\right) \sqrt{\frac{4 h^{3}}{3 H_{b}^{2} D}}}{}\right] / 2 H_{b}^{2}(r D-h) \cdots \cdots(37
\end{aligned}
$$

ただし，初期条件より $b_{0}=b_{1}=0$ となる. したがって， 式 (30)，(31)，(33)，(34）および（37）より, 先端軌 跡と先端移動速度に関する第一近似解として次式が得ら れる.

$$
\begin{aligned}
& a=\left(r-\frac{h}{D}\right) c_{s} t-g K H_{b}^{2}(r D-h) t^{2} / 2 \\
& \cdot\left[-\left\{\frac{D}{r}(r D-h)^{2}+\frac{K}{2 r \mu} H_{b}^{2} D \sqrt{\frac{4 h^{3}}{3 H_{b}^{2} D}}\right\}\right. \\
& +\sqrt{\frac{D^{2}}{r^{2}}(r D-h)^{4}+\frac{K^{2}}{3 r^{2} \mu^{2}} H_{b}^{2} h^{3} D} \\
& \left.+\frac{K}{r^{2} \mu} H_{b}^{2} D^{2}\left(r^{2} D^{2}-h^{2}\right) \sqrt{\frac{4 h^{3}}{3 H_{b}^{2} D}}\right] \\
& \dot{a}=\left(r-\frac{h}{D}\right) c_{s}-g K H_{b}^{2}(r D-h) t /\left[-\left\{\frac{D}{r}(r D-h)^{2}\right.\right. \\
& +\frac{K}{2 r \mu} H_{b}^{2} D \sqrt{\frac{4 h^{3}}{3 H_{b}^{2} D}} \\
& +\sqrt{\frac{D^{2}}{r^{2}}(r D-h)^{4}+\frac{K^{2}}{3 r^{2} \mu^{2}} H_{b}^{2} h^{3} D} \\
& \left.+\frac{K}{r^{2} \mu} H_{b}^{2} D^{2}\left(r^{2} D^{2}-h^{2}\right) \sqrt{\frac{4 h^{3}}{3 H_{b}^{2} D}}\right]
\end{aligned}
$$

また，波高減衰は，式 (22) の第 1 行目の関係式，すな わち理想段波モデルの関係式を $H_{\xi}\left(=h+\eta_{b}\right)$ について 解いて整理すれば得られ, 近似的に

$$
\begin{aligned}
& \frac{\eta_{b}}{h}=\frac{1}{2}\left[\sqrt{\frac{H_{a}^{2}}{h^{2}}+\frac{8}{g r^{2} h}\left(\dot{a}+\frac{h}{H_{a}} c_{s}\right)^{2} \frac{H_{a}}{h}}-\frac{H_{a}}{h}\right]-1 \\
& \frac{X^{\prime}}{h}=\left(a+c_{s} t\right) / h
\end{aligned}
$$

ここで, $\eta_{b}$ : 砕波後の波の静水面からの最大水位で, 本 モデルでは $H_{\mathrm{s}}-h, X^{\prime}$ : 固定座標系での段波先端位置.

\section{4. 解の性質と適用性}

前章で得られた結果の性質と実際問題への適用性につ いて, 具体的計算例と実験結果との比較を通して検討す ることにする.

\section{（1）解の性質}

図一3 は第一近似と第二近似の固定座標系での先端軌 跡を示したものである. 図中の（）内の数値がその近 似度を示している.この図によると, 第一近似解と第二 近似解は広い範囲にわたってほぼ同じ結果を示してお り，第一近似解はかなりの範囲まで適用可能であること が伺われる.よって, 以下の理論計算例ではすべて第一 近似解を用いることにする.

図一 4 と 5 は抵抗係数を種々と変化させた場合の先端 軌跡と波高減衰を示したものである. 図一 5 には $K=$ 0.01 と 0.002 の場合の段波先端での静水面からの水位 （破線）も示されている. 図一4によると, 本研究で対

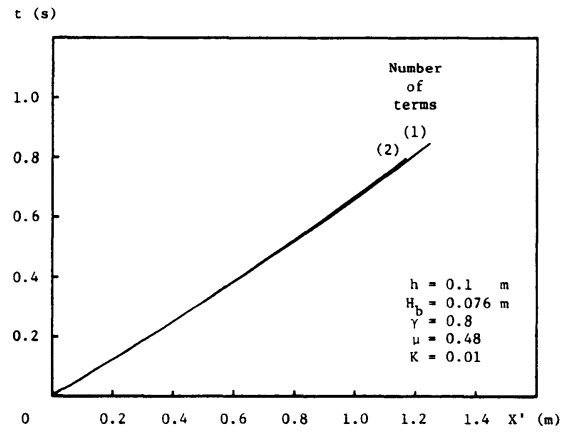

图一3 段波先端軌跡に関する級数解の収束例

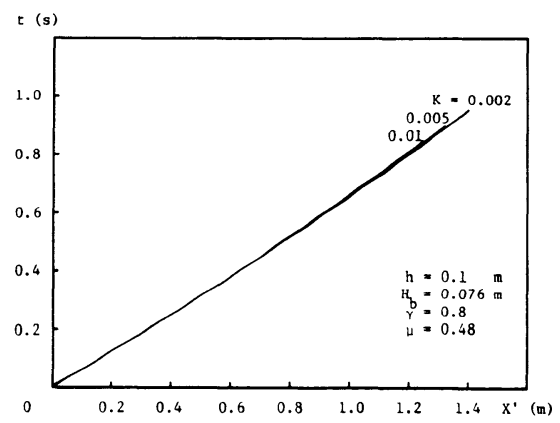

图一4段波先端隺跡の抵抗係数による变化 


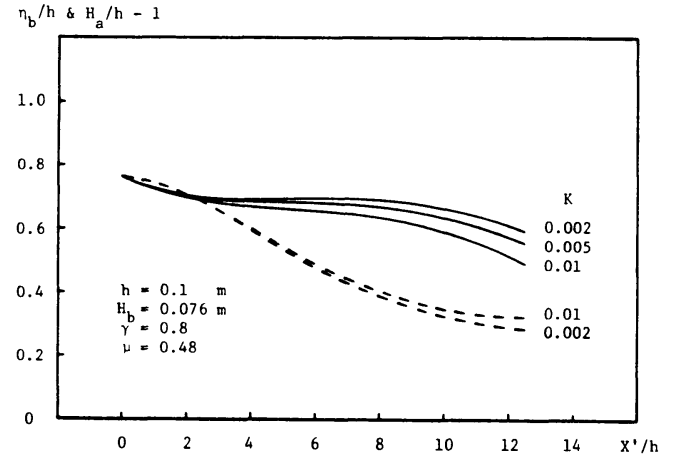

図一5 波高娍表の抵抗係数による変化

象とした段波の先端軌跡は抵抗にあまり影響されないこ とがわかる.このことは図一5からも伺うことができる. 段波先端での水位の抵抗係数による変化は比較的小さ い. しかし，同じく図-5からわかるように，波高減衰 は抵抗係数の值によりかなり大きく変化する．このこと は, 前章の結果を実際問題へ適用する際に，抵抗係数の 選択が重要因子となることを示唆している，また，図一 5 は抵抗係数が大きくなると段波波高が小さくなること を示している，ただし，これは $H_{b}, r$ や $\mu$ が同じとし てのことである. 後に示される図-8 と図-10 の実験結 果を比較すれば，抵抗係数（底面粗度）が変化すると， 両者の段波波高はほぼ同じであるが，砕波波高は少し異 なってきている．よって，この理論結果の妥当性は本実 験ケースのみでは確認できず，今後のより正確な実験を 必要とする．さらに，本モデル結果には砕波形成直後の 短い間，段波波頂での水位（図一5 での実線）が段波先 端での水位（同図中の破線）よりも小さいという実際に は起こり得ない不合理が生じている.これは， $\mu$ が定数 とされ, $r$ として本モデルの適用範囲での平均的な值 が採用されており，しかも非定常項と抵抗項の影響を無 視した式（22）の理想段波式から誘導される式（40）を 用いて段波波頂水位が評価されていることによる。

\section{（2）解の適用性}

実験に使用した水路は高さ $0.5 \mathrm{~m}$, 幅 $0.3 \mathrm{~m}$, 長さ $11.0 \mathrm{~m}$ の水平に設置された鋼製矩形水路で, 水路下流 側の $10 \mathrm{~m}$ 部分が両面ガラス張りのものである.この水 路上流端にはプランジャ一型造波機が据え付けられてお り，孤立波はそれを一度だけ押し下げることにより造波 された。また，ガラスの片面には孤立波の波高減衰，段 波の先端軌跡, 先端水位と空間波形（5. で議論する） 読み取りのため, $5 \mathrm{~cm}$ 間隔のメッシュが刻まれている. 実験装置の概要を図一6に示す.

実験ケースは静水深を $0.1 \mathrm{~m}$ に固定し, 底面栈粗度 $(5 \times 5 \times 300 \mathrm{~mm}$ の角柱木製栈を水路縦断方向に $5 \mathrm{~cm}$

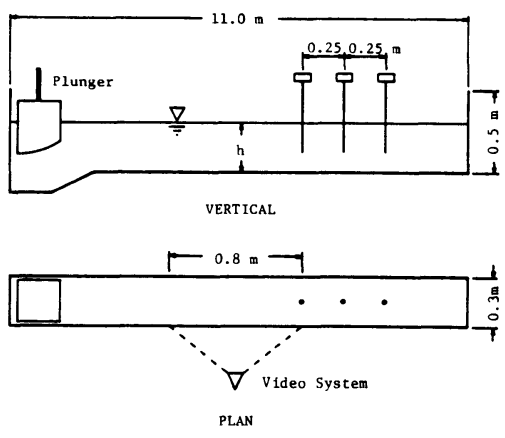

图一6 実検装是

間隔で設置) 有無とした 2 ケースである．測定項目とそ の方法は空間波形についてはモーター・ドライブ・カメ ラ (約 5 コマ/秒)，波高减衰と段波の先端軌跡，先端 水位はビデオ・システムと 3 台の容量式波高計である。 ここで，ビデオの撮影範囲は砕波点より約 $0.1 \mathrm{~m}$ 手前 から $0.8 \mathrm{~m}$ 先までとし, その終点付近に $0.25 \mathrm{~m}$ 間隔て 設置された第一本目の波高計が入るようにした。ビデオ の解析には $1 / 60$ 秒まで読み取り可能なビデオ・モ一 ション・アナライザーを，波高計の出力記録にはペン・ レコーダーを用いた。

先端軌跡に関する第 1 近似解と実験值（栈粗度なし） との比較を図ー7に示す. 実験値は 5 波分で, 実線が理 論曲線である. この理論曲線は $r=0.8$ と固定し, 実験 值によく適合するように ものである. ただし，抵抗係数としては Manning の粗 度係数を推定し（底面と側壁ともに $n=0.013 \mathrm{~m}^{-1 / 3} \mathrm{~s}$ ), 本モデルの適用範囲内での平均的水位から計算される径 深 $R$ を用いて換算 $\left(K=g n^{2} / R^{1 / 3}\right)$ されたものが採用 されている. 合成補正係数 $r=0.8$ の值は Boussinesq 理論において, 砕波限界の誘導の際と同じく, $0\left(\eta^{2} / h^{2}\right)$ または $0\left(H_{b}^{2} / h^{2}\right)$ の項まで考慮して議論すれば概略説 明のつくものであり (補遗参照), $\mu=0.48$ は図一2の 円弧を図中の直線で近似したことを意味する．図一7に は孤立波の伝播速度で動く点の軌跡（一点鎖線）と $r$ $=1$ としたときの段波初速度で動く点の軌跡（破線）も 示されている。

図一8は孤立波の波高減衰（実線）と段波先端での静 水面からの水位（破線）の理論値と実験値との比較を示 したものである．実験值は図一7で使用した波と同一の 波から得られたもので，黒丸が波高減衰，白丸が段波先 端での水位を示す。この図によると，砕波直後の短い間 を除いて, 波高減衰と段波先端での水位に関する本研究 の結果は実用に供し得るものであると判断される.

図一 9 と 10 は, 底面条件を変化させた場合（栈粗度 あり）の段波先端軌跡および波高減衰と段波先端の静水 


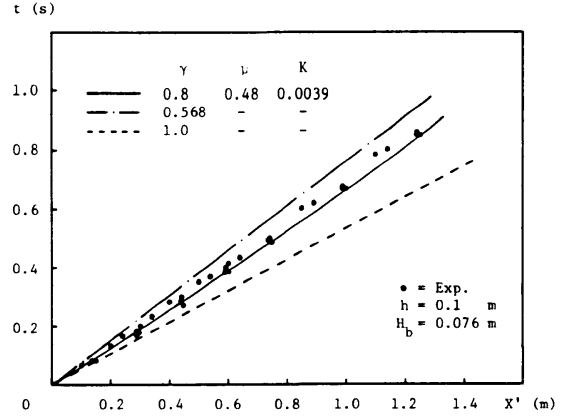

図一7段波先端軌跡の実硂值との比較

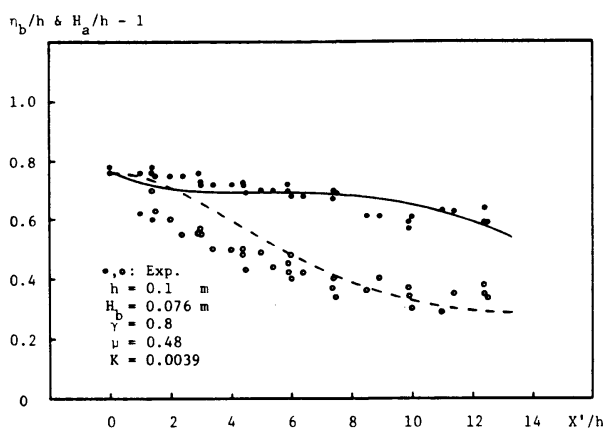

図一8 波高減表の実験值との比較

面からの水位について, 理論值と実験値との比較を示し たものである. 実験值は同じく 5 波分で, 図中の各線の 意味はおのおの図一 7,8 と同じである. また, 理論に おける抵抗係数は底面と側壁の $n$ をおのおの 0.022 と $0.013\left(\mathrm{~m}^{-1 / 3} \mathrm{~s}\right)$ として Einstein の方法 ${ }^{11}$ により合成粗 度係数を求め, あとは図一8でのときと同じようにして 推定されている。これらの図より，底面条件に応じた抵 抗係数を採用すれば, 3. の結果は $r=0.8, \mu=0.48$ と してほぼ実用に供し得ることが判断される。

以上より, 砕波直後の短い間を除いて, 本モデルは波 高減衰および段波の先端軌跡とその高さを同時に予測で きるモデルであると判断される.

\section{5. 換算ダム破塿流れ法による水面形の推定}

定常跳水や砕波段波の流れの場に関する実験的研究が 従来より数多く行われてきているが，その結論の 1 つは それらの混合領域での流れの場が壁面噴流 ${ }^{12}$, 自由世ん

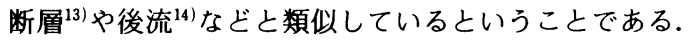
これから推して，ダム破壊流れ先端部と孤立波の崩れ波 型砕波の流れの場は同じ非定常な研波段波として類似し ているものと考えられる. そこで，本章では孤立波の砕 波段波をダム破壊流れの砕波段波に換算し，著者の手 法占)によりその換算された段波の水面形を求め, それが

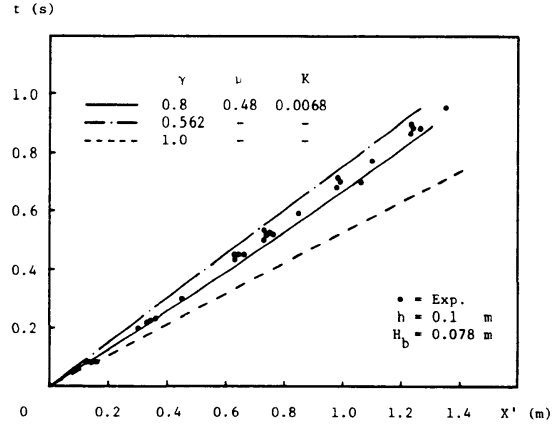

图一9段波先端軌跡の実挽值との比較

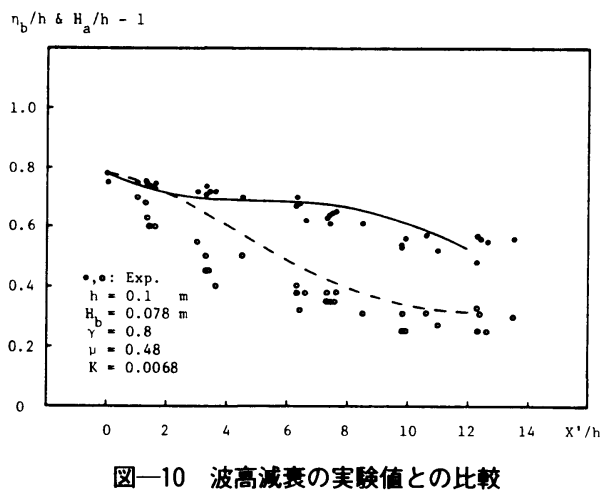

孤立波の崩れ波型砕波の水面形の推定値として妥当なも のであるかどうか検討することにする.

この水面形推定手法では段波波高・段波伝播速度と段 波波長が与えられれば，ダム破壊流れの段波を初期のダ 厶上・下流側水深比 $h_{1} / h_{0}$ をパラメーターとして特定 できる. 孤立波の崩れ波型砕波による段波の任意時刻で の段波波高 $\Delta H$, 段波伝播速度 $\dot{a}_{e}$ と段波波長 $L_{\mathrm{e}}$ はお のおの

$$
\begin{aligned}
& \Delta H=H_{s}-H_{a} \\
& \dot{a}_{e}=\dot{a}-U_{a} \cdots \\
& L_{s}=a-\xi \cdots .
\end{aligned}
$$

ここで, 段波は速度 $U_{a}$ で動く移動座標系で表現されて いる.これは段波下流側の流速が零, すなわち, 静水中 を伝播する段波を想定していることにあたる．よって， 換算ダム破壊流れの初期下流側水深 $h_{0}$ は， $h_{1} / h_{0}$ をパ ラメーターとして, 次式の Ritter 理論(6) より求められる。

$$
\begin{aligned}
2 \sqrt{\frac{h_{1}}{h_{0}}} & =\frac{U_{e}}{c_{0}}+2 \sqrt{\frac{\Delta H}{h_{0}}+1} \\
& =\varepsilon \frac{\dot{a}_{e}}{c_{0}}+2 \sqrt{\frac{\Delta H}{h_{0}}+1}
\end{aligned}
$$

ここで, $U_{e}$ ：換算水粒子速度, $\varepsilon: U_{e}$ と $\dot{a}_{e}$ の比で時間 的に不変な値, $c_{0}=\sqrt{g h_{0}}$. すなわち, 任意の $h_{1} / h_{0}$ を 仮定し（ただし，水面形推定手法の適用可能範囲内での 


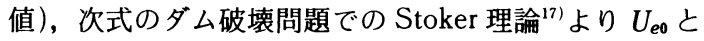
$\dot{a}_{e 0}$ を求めて $\varepsilon\left(=U_{e 0} / \dot{a}_{e 0}\right)$ を決定すれば $h_{0}$ が一義的に 定まることになる.

$$
\begin{aligned}
& \frac{U_{e 0}}{c_{0}}=\frac{\dot{a}_{e 0}}{c_{0}}-\frac{c_{0}}{4 \dot{a}_{e 0}}\left[1+\sqrt{1+8\left(\frac{\dot{a}_{e 0}}{c_{0}}\right)^{2}}\right] \\
& \frac{\sqrt{g H_{0}}}{c_{0}}=\left[\frac{1}{2}\left\{\sqrt{1+8\left(\frac{\dot{a}_{e 0}}{c_{0}}\right)^{2}}-1\right\}\right]^{\frac{1}{2}} \\
& \frac{U_{e 0}}{c_{0}}+2 \frac{\sqrt{g H_{0}}}{c_{0}}=2 \frac{c_{1}}{c_{0}}
\end{aligned}
$$

ここで, $U_{e 0}$ ：換算初期水粒子速度, $\dot{a}_{e 0}$ ：換算初期先端 移動速度, $H_{0}$ : 換算初期段波水深, $c_{1}: \sqrt{g h_{1}}$. 水面形 推定手法の適用可能範囲は $\dot{a}_{e 0}>\dot{a}_{e}$ という条件より求め られる. $h_{0}$ が決まれば $h_{1}$ も定まることになる.したがっ て, ダム破壊流れの先端移動速度と段波波長に関する第 一近似解 ${ }^{10)}$, 15)

$$
\dot{a}_{e}=\dot{a}_{e 0}-\varepsilon g \frac{1-\left(\frac{3}{2} \varepsilon-1\right) \dot{a}_{e 0 *}}{3 \frac{h_{0}}{h_{1}} \dot{a}_{e 0 *}+2\left(1-\frac{\varepsilon}{2} \dot{a}_{e 0 *}\right)^{3}} \dot{a}_{e 0 *}^{2} K_{e} t_{e}
$$

$$
\begin{aligned}
& L_{\mathrm{s}}=a-\xi=a_{e}-\xi_{e} \\
& =\dot{a}_{e 0} t_{e}-\varepsilon g \frac{1-\left(\frac{3}{2} \varepsilon-1\right) \dot{a}_{e 0 *}}{6 \frac{h_{0}}{h_{1}} \dot{a}_{e 0 *}+4\left(1-\frac{\varepsilon}{2} \dot{a}_{e 0 *}\right)^{3}} \dot{a}_{e 0 *}^{2} K_{e} t_{e}^{2} \\
& -\left(\frac{3}{2} U_{e}-c_{1}\right) t_{e}
\end{aligned}
$$

に以上の諸換算結果を代入すれば換算抵抗係数 $K_{e}$ と換 算時間 $t_{e}$ が求まり, 換算ダム破壊流れとその水面形決 定に必要とされる量がすべて求められることになる。こ こで, $\dot{a}_{e 0 *}=\dot{a}_{e 0} / c_{1}, a_{e}$ ：換算ダム破壊流れ先端位置, $\xi_{e}$ : 換算ダム破壊流れ後端位置. そして, 以上の換算諸 量を用いて水面形は次の手順で求められる ${ }^{15)}$.

i ) 式 (48)の関係を満たす $v_{0 e}$ と $h_{e}$ の組 $\left(v_{0 e *}, h_{e *}\right)$ を式 (49) および（50）より求める.

$$
\begin{aligned}
& h_{e}=h_{0}+\frac{1}{g} v_{0 e} \dot{a}_{e}-\frac{1}{2 g} v_{0 e}^{2} \\
& v_{0 e}=\dot{a}_{e}-\left(\dot{a}_{e}-U_{e}\right) \sqrt{\frac{a_{e}-\xi_{e}}{a_{e}-x_{e}}} \\
& h_{e}=2 \sqrt[3]{\theta} \cos \frac{\varphi}{3}+\frac{2}{3 g} s_{5}\left(\dot{a}_{e}-U_{e}\right)^{2} \frac{a_{e}-\xi_{e}}{a_{e}-x_{e}} \\
& \theta=\sqrt{-\frac{m^{3}}{27}}, \cos \varphi=-\frac{q}{2 \theta}, \\
& m=-\left[\frac{4}{3 g^{2}} s_{5}^{2}\left(\dot{a}_{e}-U_{e}\right)^{4}\left(\frac{a_{e}-\xi_{e}}{a_{e}-x_{e}}\right)^{2}-\frac{4}{g} s_{5} \dot{a}_{e}\right. \\
& \cdot\left(\dot{a}_{e}-U_{e}\right) h_{0} \sqrt{\frac{a_{e}-\xi_{e}}{a_{e}-x_{e}}}+\frac{2}{g} \dot{a}_{e}^{2} h_{0}+h_{0}^{2} \\
& \left.+\frac{2}{g} K_{e} U_{e}^{2}\left(a_{e}-x_{e}\right)\right] \text {, }
\end{aligned}
$$


$2(\mathrm{~cm})$

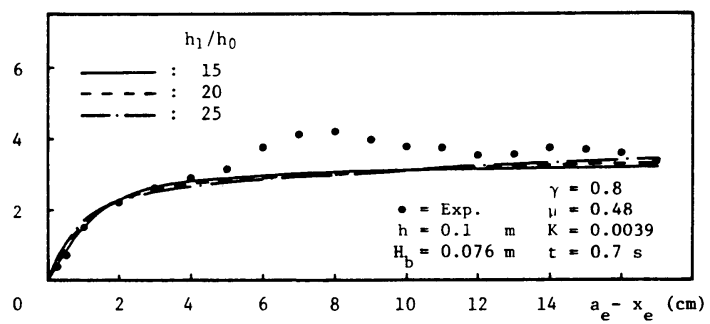

図一11换算ダム破接流れ法による水面形の実殹值との比较

の崩れ波型砕波による段波の実状（この場合の段波波高 と段波下流側水深との比はどの想定された $h_{1} / h_{0}$ での その比よりも小さい）により近づくということである. よって,このことは推察され得ることである. また, 実 験值は瞬間值であるため波打ち, 推定值と大きくずれて いるところも一部分見受けられるが, 段波先端部や後端 部などの大部分で両者はよく一致しており, 孤立波の崩 れ波型砕波の水面形の推定に本章の方法がかなり有効で あることが認められる. よって, 砕波直後の短い間を除 いて, 本研究の結果は実際の孤立波の崩れ波型砕波によ る波高減衰や砕波段波の先端軌跡, 高さと水面形を統一 的に推定し得るものであると判断される.

\section{6. むす び}

1983 年日本海中部地震津波の際, 秋田県北部海岸で みられたように，津波は陸岸近くでソリトン波列や分裂 には至らない孤立的な波を形成することがあり，これら の個々の波が孤立波とみなせるとすると, 孤立波の砕波 変形問題は津波においても重要な問題となる.しかるに, 現在までに得られているこの問題についての知見は十分 とはいいがたい.

本研究は波や流れの場の簡単なモデル化により孤立波 の崩れ波型砕波による波高減衰や砕波段波の先端軌跡, 高さと水面形の理論的推定を試みたものである. 本モデ ルには砕波形成直後の短い間, 段波背後の水位が段波先 端での水位よりも小さくなるという不合理や適用範井が 狭いという改良すべき点などがあるが，その結果はおよ そ $r=0.8, \mu=0.48$ とすることで実際の孤立波の崩れ 波型砕波による中間段階（工学的に最も重要な段階と思 われる) の波高減衰および砕波段波の先端軌跡, 高さと 水面形の概略的推定に供することができる.

謝辞: 本研究を遂行するにあたり, 東北大学工学 部首藤伸夫教授と秋田大学鉱山学部浅田 宏教授より 有益なるご教示，ご意見を賜った。ここに記して両先生 に深甚なる感謝の意を表する.なお, 本研究の一部は昭 和 61 年度文部省科学研究費自然災害特別研究 (1)
（研究代表者：東北大学工学部首藤伸夫教授）により 行われたことを付記する.

\section{補遗 合成補正係数 $\boldsymbol{r}$ の理論的評価}

理論の一貫性を考えてここでも Keulegan and Patterson の Boussinesq 理論を採用することにする ${ }^{9)}$.

固定座標系における孤立波の任意点での水平方向水粒 子速度 $u_{z}$ は

$$
u_{z}=\sqrt{\frac{g}{h}} \eta\left[1-\frac{\eta}{4 h}+\left\{h^{2}-\frac{3}{2}(h+z)^{2}\right\}\left(\frac{H_{b}}{h^{3}}-\frac{3 \eta}{2 h^{3}}\right)\right]
$$

よって, 運動量補正係数 $\beta$ の定義式

$$
\beta(h+\eta) u^{2}=\int_{-h}^{\eta} u_{z}^{2} d z
$$

に式 (S-1) を代入し, Boussinesq 理論による砕波限 界の誘導の際と同じく0 $\left(\eta^{2} / h^{2}\right)$ または $0\left(H_{b}^{2} / h^{2}\right)$ の 項まで考慮して $\beta$ を評価することにすれば， $\beta$ として 次式を得る.

$$
\begin{aligned}
\beta= & \left(1+\frac{\eta}{h}\right)^{2}\left(1-2 \frac{\eta}{h}+\frac{H_{b}}{h}+\frac{89}{20} \frac{\eta^{2}}{h^{2}}-\frac{18}{5} \frac{H_{b} \eta}{h^{2}}\right. \\
& \left.+\frac{9}{20} \frac{H_{b}^{2}}{h^{2}}\right)\left(1+\frac{H_{b}}{h}\right) \ldots \ldots \ldots \ldots \ldots \ldots \ldots \ldots \ldots \ldots \ldots \ldots \ldots \ldots \ldots \ldots \ldots
\end{aligned}
$$

式（S-3） は固定座標系でのものである. 孤立波の伝播 速度で動く移動座標系での運動量補正係数 $\beta^{\prime}$ は次式か ら得られる。

$$
\int_{-h}^{n} u_{z}^{2} d z=\int_{-h}^{n}\left(U+c_{s}\right)^{2} d z
$$

その結果は

$$
\beta^{\prime}=\beta \frac{\eta^{2}}{h^{2}}-2 \frac{\eta}{h}\left(1+\frac{\eta}{h}\right)+\left(1+\frac{\eta}{h}\right)^{2} \cdots
$$

一方, Boussinesq 理論による孤立波の任意点での圧 力 $p$ は, 式 (S-6) より求められる. 圧力に関しては固 定・移動座標系の別はない.

$$
\begin{aligned}
\frac{p}{\rho}= & \frac{\partial \phi}{\partial t}-g z-\frac{1}{2}\left[\left(\frac{\partial \phi}{\partial x}\right)^{2}+\left(\frac{\partial \phi}{\partial z}\right)^{2}\right] \\
\doteqdot & \frac{\partial \phi}{\partial t}-g z-\frac{1}{2}\left(\frac{\partial \phi}{\partial x}\right)^{2} \\
\doteqdot & \frac{\partial \phi_{0}}{\partial t}-g z-\frac{1}{2}(h+z)^{2} \frac{\partial}{\partial x}\left(\frac{\partial \phi_{0}}{\partial t}\right) \\
& -\frac{1}{2}\left(\frac{\partial \phi_{0}}{\partial x}\right)^{2}+\frac{1}{2}(h+z)^{2} \frac{\partial \phi_{0}}{\partial x} \frac{\partial^{3} \phi_{0}}{\partial x^{3}}
\end{aligned}
$$

ここで， $\phi$ は速度ポテンシャルで， $\phi$ と $\phi_{0}$ との間には 近似的に次式の関係がある.

$$
\phi \doteqdot \phi_{0}-\frac{1}{2}(h+z)^{2} \frac{\partial^{2} \phi_{0}}{\partial x^{2}}
$$

そこで, 運動量補正係数と同じ精度の表示を導くことに すれば, 任意点での圧力は近似的に

$$
\frac{p}{\rho} \fallingdotseq g \eta\left(1+\frac{3}{2} \frac{H_{b}}{h}-\frac{7}{4} \frac{\eta}{h}\right)-\frac{g}{2} \frac{\eta^{2}}{h}\left(1+\frac{H_{b}}{h}-\frac{7}{4} \frac{\eta}{h}\right)^{2}
$$




$$
\begin{aligned}
& -g z-\frac{3}{2} g\left(\frac{H_{b} \eta}{h^{3}}-\frac{3}{2} \frac{\eta^{2}}{h^{3}}\right)(h+z)^{2} \\
& +\frac{3}{2} g \frac{\eta}{h}\left(\frac{H_{b} \eta}{h^{3}}-\frac{3}{2} \frac{\eta^{2}}{h^{3}}\right)\left(1+\frac{H_{b}}{h}-\frac{7}{4} \frac{\eta}{h}\right)(h+z)^{2}
\end{aligned}
$$

ただしここでは次の関係式が用いられている.

$$
\begin{aligned}
& \frac{\partial \phi_{0}}{\partial t} \doteqdot g \eta\left(1+\frac{3}{2} \frac{H_{b}}{h}-\frac{7}{4} \frac{\eta}{h}\right) \\
& \frac{\partial \phi_{0}}{\partial x} \doteqdot-\sqrt{\frac{g}{h}} \eta\left(1+\frac{H_{b}}{h}-\frac{7}{4} \frac{\eta}{h}\right) \\
& \frac{\partial^{2}}{\partial x^{2}}\left(\frac{\partial \phi_{0}}{\partial t}\right) \doteqdot g \frac{\partial^{2} \eta}{\partial x^{2}}=3 g\left(\frac{H_{b} \eta}{h^{3}}-\frac{3}{2} \frac{\eta^{2}}{h^{3}}\right) \ldots \\
& \frac{\partial^{3} \phi_{0}}{\partial x^{3}} \doteqdot-\sqrt{\frac{g}{h}} \frac{\partial^{2} \eta}{\partial x^{2}}=-3 \sqrt{\frac{g}{h}}\left(\frac{H_{b} \eta}{h^{3}}-\frac{3}{2} \frac{\eta^{2}}{h^{3}}\right)
\end{aligned}
$$

任意地点での単位幅当たりの全圧力 $P$ は

$$
\begin{aligned}
\frac{P}{\rho}= & \int_{-h}^{\eta} \frac{p}{\rho} d z \\
\doteqdot & \frac{g}{2} h^{2}\left(1-\frac{\eta^{2}}{h^{2}}\right)+g h^{2} \frac{\eta}{h}\left(1+\frac{3}{2} \frac{H_{b}}{h}-\frac{3}{4} \frac{\eta}{h}\right) \\
& -\frac{g}{2} \eta^{2}-\frac{g}{2} h^{2}\left(\frac{H_{b} \eta}{h^{2}}-\frac{3}{2} \frac{\eta^{2}}{h^{2}}\right) \ldots \ldots \ldots \ldots \ldots . . .
\end{aligned}
$$

そして,$r$ は以上の諸結果を用いて次式で評価される ことになる.

$$
\begin{aligned}
\frac{g}{2} r^{2}\left(H_{\xi}^{2}-H_{a}^{2}\right)= & \frac{P_{\xi}}{\rho}-\frac{P_{a}}{\rho}+\left(\beta_{\xi}^{\prime}-1\right) H_{\xi} U_{\xi}^{2} \\
& -\left(\beta_{a}^{\prime}-1\right) H_{a} U_{a}^{2} \ldots \ldots \ldots \ldots \ldots \ldots
\end{aligned}
$$

ここで, 添字はそれぞれの位置での值であることを表わ す.

図一10から判断されるように, この場合の本モデル の適用範囲での平均的な $H_{\xi}$ と $H_{a}$ はそれぞれおよそ $0.16 \mathrm{~m}$ と $0.13 \mathrm{~m}$ である. したがって, これらの值を考 慮して式 $(\mathrm{S}-14)$ より $r$ を評価すれば

$$
r \fallingdotseq 0.838
$$

が得られることになる.これは夷験值によく適合するよ うにして決められた $r=0.8$ 亡類似の値である. その差 は Boussinesq 理論そのものの適用度に帰着されるもの と思われる.

\section{参 考 文 献}

1）椹木 享: 砕波特論, 第 9 回水工学研修会講義集, 土木 学会, pp. B-2-1 B-2-38, 1973.
2) 堀川清司編：海岸環境工学, 東京大学出版会, pp. 80 83,1985

3）たとえば, 西村仁胴：海浜循噮流の数値シミュレーショ ン, 第 29 回海講論文集, pp. 333 337, 1982.

4）たとえば，松冨英夫・浅田 宏・橪岡善治：砕波段波街 突による波力の一評価方法, 第 34 回海講論文集, 1987 , (印刷中).

5）首藤伸夫：秋田県北部海岸における日本海中部地震津波, 第 31 回海講論文集, pp. 247 251, 1984.

6) Horikawa, K. and Kuo, C. T. : A study on wave transformation inside surf zone, Proc. of 10th Coastal Eng. Conf., ASCE, pp. 217 233, 1966.

7）椹木 享・岩田好一朗・松本 昇: 砕波後の波の底面摩 擦力に関する実験的研究, 第 21 回海講論文集, pp. 33 $38,1974$.

8）泉宮尊司・堀川清司：砕波帯における波のエネルギー方 程式のモデリング, 第 30 回海講論文集, pp. 15 19, 1983.

9) Boussinesq, J. : Théorie de l'intumescence liquide appelée onde solitaire ou de translation se propagant dans un canal rectangulaire, Institut de France, Académie des Science, Comptes Rendus, p. 755, 1871.

または, 本間 仁・安芸盿一編：物部水理学, 岩波書店, pp. 493 495, 1972.

10）松富英夫：下流側水深を有する場合の夕破壊流れにつ いて, 土木学会論文集, No. 363/ II -4, pp. 79 86, 1985.

11) Chow, V.T. : Open-Channel Hydraulics, McGraw Hill, pp. 136 140, 1959.

12）たとえば, Rajaratnam, N. : The hydraulic jump as a wall jet, Proc. of ASCE, Vol. 91, No. HY5, pp. 107 $\sim 132,1965$.

13) Peregrine, D.H. and Svendsen, I. A. : Spilling breakers, bores and jumps, Proc. of 16th Coastal Eng. Conf., ASCE, pp. 540 550, 1978.

14) Battjes, J. A. and Sakai, T. : Velocity field in a steady breaker, Jour. of Fluid Mech., pp. 421 437, 1981.

15）松富英夫：下流側水深を有する夕゙ム破壊流れ先端部の水 面形, 土木学会論文集, No. $375 /$ II -6, pp. 161 170, 1986.

16) Ritter, A. : Die Fortpflanzung der Wasserwellen, Zeitschrift des Vereines deutscher Ingenieure (Berlin), Vol. 36, pt. 2, No. 33, pp. 947 954, 1982.

17) Stoker, J. J. : Water Waves, Interscience Publishers, Inc., New York, pp. 333 341, 1957.

(1987.1.7 • 受付) 